\title{
AR Gene
}

National Cancer Institute

\section{Source}

National Cancer Institute. AR Gene. NCI Thesaurus. Code C28539.

This gene plays a role in the transcriptional activation of androgen responsive genes. 